\title{
POTENSI DESA WISATA PENGLIPURAN MENURUT MAHASISWA KEPARIWISATAAN POLITEKNIK PARIWISATA BALI
}

\author{
Anom Hery Suasapha \\ Program Studi Destinasi Pariwisata, Politeknik Pariwisata Bali \\ Jl. Dharmawangsa Kampial, Nusa Dua Bali \\ anom_hs@yahoo.com
}

\begin{tabular}{l|l|l} 
Received: Agustus, 2020 & Accepted: September, 2020 & Published: September, 2020
\end{tabular}

\begin{abstract}
This article is written based on a research conducted on 2019. The research was a quantitative research, to determine the tourism potential of Penglipuran Village through the perception of Tourism Students of Bali Tourism Polytechnic. In doing so, quantitative as well as qualitative data were collected from primary and secondary source. The primary data which will be analyze were collected through survey method, using a self-administered questionnaire. The questionnaire was a Likert Scale Questionnaire, with five (5) respond category, consist of extremely disagree, disagree, neutral, agree and extremely agree. Secondary data were collected through documentation. Respondent were determined purposively, and on field, the surveyor determined the respondent accidentally. Data were then analyzed using Exploratory Factor Analysis, to produce result in the form of factors indicating the tourism potentials of Penglipuran Village. This research shows that the tourism potency of Penglipuran Village consists of those of Strength and those of Opportunity.
\end{abstract}

Keywords: village tourism, penglipuran, students perception

\begin{abstract}
Abstrak
Artikel ini membahas persepsi mahasiswa kepariwisataan Politeknik Pariwisata Bali terhadap potensi wisata Desa Wisata Penglipuran, Kabupaten Bangli. Penelitian ini menggunakan pendekatan kuantitatif, dilakukan pada tahun 2019. Data yang dikumpulkan merupakan data kuantitatif dan kualitatif, baik dari sumber primer maupun sekunder. Data primer diperoleh melalui metode survei, dengan mempergunakan instrumen berupa kuesioner Skala Likert yang memiliki lima (5) pilihan respon. Data sekunder dikumpulkan melalui studi pustaka. Responden ditentukan secara purposif dan pemilihannya di lapangan dilakukan dengan pendekatan insidental. Data yang terkumpul dianalisis dengan teknik Analisis Faktor Ekploratori, sehingga menghasilkan faktor-faktor baru yang menunjukkan potensi Desa Wisata Penglipuran. Penentuan jumlah responden dilakukan berdasarkan pendapat para pakar mengenai jumlah sampel spesifik untuk Analisis Faktor. Hasil analisis menunjukkan bahwa secara internal, Desa Wisata Penglipuran memiliki beberapa kekuatan sebagai potensinya, dan secara eksternal didukung oleh beberapa peluang.
\end{abstract}

Kata Kunci: desa wisata, penglipuran, persepsi mahasiswa 


\section{PENDAHULUAN}

Desa Wisata Penglipuran berawal dari upaya konservasi yang dilakukan oleh warganya dalam menjaga kelestarian budaya khususnya bangunan tradisional yang terdapat di setiap rumah penduduk Desa Adat Penglipuran. Upaya konservasi tersebut selanjutnya menjadikan Desa Penglipuran sebagai destinasi pariwisata yang menawarkan keunikan budaya Bali Aga (Bali asli) di Bali yang banyak dikunjungi oleh wisatawan asing maupun domestik. Daya tariknya, khususnya kebersihannya telah menjadikan Desa Wisata Penglipuran dinobatkan sebagai desa terbersih ketiga di dunia pada tahun 2017 (www.indonesia.travel).

Artikel ini membahas mengenai potensi wisata yang dimiliki oleh Desa Wisata Penglipuran, berdasarkan persepsi mahasiswa kepariwisataan Politeknik Pariwisata Bali. Hal tersebut memiliki setidaknya 2 kepentingan, yaitu mengingat bahwa perkembangan Desa Wisata Penglipuran dimulai dari penetapannya sebagai desa konservasi, yang berbeda pendekatannnya dengan pengembangan destinasi pariwisata ataupun daya tarik wisata. Selain itu, berdasarkan penelusuran, tidak ditemukan adanya penelitian yang mengungkap mengenai potensi wisata Desa Wisata Penglipuran

Untuk memperoleh gambaran mengenai potensi wisata tersebut, penelitian terhadap persepsi dianggap sebagai cara yang tepat. Alasannya adalah karena pendekatan tersebut mampu menghasilkan data dari banyak orang sehingga memaksimalkan objektivitas data yang dikumpulkan. Responden yang persepsinya digali untuk mengetahui potensi wisata Desa Penglipuran adalah mahasiswa Jurusan Kepariwisataan dari program studi Destinasi Pariwisata dan Manajemen Kepariwisataan, Politeknik Pariwisata Bali.

Mahasiswa dipilih sebagai responden dikarenakan mahasiswa merupakan salah satu dari kelompok
Academia, yang merupakan salah satu bagian dari stakeholder selain masyarakat, pemerintah dan swasta (Calzada \& Cowie, 2017). Academia merupakan kelompok stakeholder yang terdiri dari para pelajar, mahasiswa serta Profesor (www.vocabulary.com). Dilihat dari sudut pandang pariwisata, mahasiswa merupakan stakeholder yang menarik karena selain menjalankan peran sebagai akademisi, mahasiswa juga merupakan golongan muda yang memiliki kemampuan untuk memberikan pengaruh kepada banyak hal, termasuk dalam hal berwisata. Selain itu, mahasiswa sebagai kaum muda (youth) juga memiliki banyak keunggulan sebagai segmen pasar wisata yang potensial. Meskipun secara pendapatan mereka relatif lebih sedikit, namun dampak dari pengeluaran yang mereka lakukan di destinasi biasanya dirasakan langsung oleh masyarakat. Dengan ketersediaan waktu yang lebih banyak dibandingkan generasi yang lebih tua, para pemuda juga tidak mudah terpengaruh oleh isu-isu khususnya yang berkaitan dengan keamanan di destinasi pariwisata. Selain itu, para pemuda biasanya banyak terlibat dalam kegiatan kerelawanan, berkontribusi terhadap perkembangan industri lain, serta mampu mempopulerkan sebuah daya tarik wisata maupun destinasi melalui akses mereka terhadap social media maupun internet (UNWTO, 2016). Kaum muda dianggap sebagai kaum yang penuh ide, rencana maupun harapan di masa depan (UNWTO, 2016). Pendapat kaum muda mencerminkan idealisme yang didasari dengan intelektualitas mereka. Karena itu, adalah sangat pantas jika pendapat mereka diperhatikan.

$$
\text { Desa Wisata Penglipuran }
$$
merupakan sebuah desa wisata. Sebagai desa wisata, berarti bahwa Pengpiran merupakan destinasi pariwisata. Karena itu, penggalian potensi dalam penelitian ini didasarkan kepada pendapat beberapa pakar mengenai komponen destinasi wisata. Dengan menguraian pendapat pakar mengenai komponen 
Suasapha

destinasi, akan diperoleh variabel maupun indikator yang bisa menjadi dasar untuk menyusun pernyataan penyusun instrumen penelitian.

Burkart dan Medlik menyatakan bahwa sebuah tempat akan bisa berkembang dengan baik apabila memiliki 4 komponen yang disebut sebagai The Tourist Qualities of a destination. Keempat komponen tersebut adalah atraksi wisata, aksesibilitas, fasilitas wisata serta organisasi kepariwisataan. UNWTO (2016) menyatakan bahwa komponen destinasi pariwisata terdiri atas atraksi wisata, akses, amenitas, harga, SDM dan citra destinasi. Keenam komponen tersebut disebut sebagai The Basic Element of a Tourist Destination.

Seperti halnya Burkart dan Medlik, Cooper (2016) menyatakan bahwa ada 4 komponen destinasi pariwisata, yang diistilahkan sebagai The Four A's of a Destination. Keempat (4) komponen tersebut terdiri atas atraksi wisata, aksesibilitas, amenitas dan ancillary service. Fletcher, dkk (2018) di sisi lain menyatakan bahwa destinasi pariwisata perlu ditunjang oleh ketersediaan 6 atribut. Keenam (6) atribut tersebut adalah memiliki wilayah yang secara geografis dikenali oleh pengunjung (logical geographical unit recognized by visitors), memiliki daya tarik wisata (Contains visitor attractions), dapat dicapai dengan mudah, atau mampu menyediakan aksesibilitas yang baik (Access or possible provision of access), memiliki jaringan transport internal (Internal transport network), memiliki ataupun mampu membangun infrastruktur maupun superstruktur bagi pengunjung (Tourist infrastructure and superstructure are present or can be developed), dan secara administrative mampu merencanakan dan

mengelola destinasi pariwisata tersebut (Administratively possible to plan and manage).

\section{METODE}

Penelitian yang mendasari penulisan artikel ini merupakan penelitian di bidang pariwisata yang dilakukan dengan pendekatan kuantitatif. Untuk itu, data primer yang dianalisis untuk memperoleh jawaban terhadap pertanyaan penelitian ini merupakan data kuantitatif. Selain itu, dikumpulkan pula data kualitatif dari beberapa sumber primer, untuk menjadi dasar bagi penulisan Laporan Penelitian khususnya di bagian pendahuluan, penelitian terdahulu, maupun gambaran umum lokasi penelitian.

Responden yang menjadi sumber primer dari pengumpulan data kuantitatif merupakan mahasiswa Jurusan Kepariwisataan, khususnya mahasiswa Program Studi Destinasi Pariwisata (DPW) Semester 5 Kelas A dan B, serta mahasiswa Program Studi Manajemen Kepariwisataan (MKP) Semester 5 Kelas A dan B. Pemilihan mahasiswa tersebut sebagai sumber primer dilakukan berdasarkan pendekatan purposif, yaitu bahwa mahasiswa yang menjadi responden haruslah mereka yang sudah pernah mengunjungi Desa Penglipuran sedikitnya sekali, dan sudah belajar cukup banyak mengenai pariwisata sehingga mampu menyampaikan persepsinya mengenai potensi Desa Wisata Penglipuran.

Instrumen yang dipergunakan untuk mengumpulkan data primer berupa kuesioner Skala Likert dengan 5 alternatif pilihan respon, yaitu Sangat Tidak Setuju (STS), Tidak Setuju (TS), Netral (N), Setuju (S) dan Sangat Setuju (SS). Pernyataan-pernyataan dalam kuesioner tersebut disusun dari hasil operasionalisasi variabel yang dilakukan terhadap pendapat-pendapat para pakar mengenai komponen destinasi pariwisata sebagai dasar penentuan potensi wisata. Adapun pakar yang dikutip pendapatnya adalah Burkart \& Medlik (1976), UNWTO (2007), Cooper (2016), dan Fletcher, et al (2018). 
Suasapha

Variabel penelitian yang diturunkan dari kelima referensi tersebut adalah: 1). Atraksi Wisata, 2). Aksesibilitas, 3) Amenitas, 4). Citra/Image, 5). Harga dan 6). SDM. Sebanyak 40 indikator diturunkan dari keenam variabel tersebut, dimana jika dikelompokkan, ke 40 indikator tersebut terdiri atas kelompok indikator internal, dan kelompok indikator eksternal mengikuti penamaan faktor-faktor internal (Internal Factor Evaluation/IFE) dan eksternal (External Factor Evaluation/EFE) yang dikutip dari David (2011). Indikator internal dan eksternal tersebut merupakan gambaran potensi internal dan eksternal dari Desa Wisata Penglipuran. Jika misalnya sebuah indikator internal disetujui oleh responden (dengan pilihan respon SS maupun S), maka indikator tersebut merupakan kekuatan (strength), dan sebaliknya, jika responden tidak menyetujuinya, (TS maupun STS) maka indikator tersebut dengan sendirinya menjadi kelemahan (weakness) dari Desa Wisata Penglipuran. Hal yang hampir sama juga berlaku terhadap indikator eksternal, dimana jika disetujui, maka indikator tersebut akan menjadi peluang (opportunity) dan jika tidak disetujui maka akan tergolong tantangan (threat).

Dengan mengacu kepada Likert (1932), sebelum dipergunakan untuk mengumpulkan data, kuesioner tersebut terlebih dahulu diujicobakan dengan menyebarkannya kepada 30 orang responden yang diambil dari populasi yang sama dengan populasi darimana sampel untuk penelitian diambil. Hal ini penting untuk mengetahui apakah kuesioner tersebut mampu menggali sikap responden sesuai dengan yang diharapkan. Item Analysis melalui uji reliabilitas dan validitas selanjutnya dilakukan terhadap hasil pengumpulan data terhadap 30 responden menggunakan software SPSS.25, dengan mengacu kepada penduan yang diberikan oleh Kencana (2018). Hasil uji reliabilitas terhadap kelompok pernyataan/indikator internal dan eksternal menghasilkan nilai Alpha Cronbach secara berurutan sebesar 0,871 dan 0,767 , yang mana nilai-nilai tersebut sudah memenuhi syarat minimum nilai Alpha Cronbach yaitu sebesar 0,7 sampai 0,9 (Kline, 2000; Field, 2017). Pemeriksaan selanjutnya terhadap output uji reliabilitas, dilakukan terhadap nilai-nilai pada kolom Corrected Item - Total Colleration, untuk mengetahui validitas setiap pernyataan dalam kuesioner. Hasil uji validitas tersebut menunjukkan secara berturut-turut ada 2 dan 4 pernyataan yang tidak valid pada kelompok pernyataan internal dan eskternal, karena nilai korelasinya lebih kecil dari syarat minimum yaitu 0,3 (Kline, 2000; Field, 2017). Untuk keenam pernyataan tersebut, perlakuan yang diberikan adalah tidak menyertakannya sebagai bagian dari instrumen untuk mengukur persepsi mahasiswa kepariwisataan PPB terhadap potensi Desa Wisata Penglipuran. Dengan pengurangan sebanyak 6 pernyataan, maka secara keseluruhan, pada akhirnya kuesioner tersebut memuat sebanyak 34 pernyataan valid, dengan perincian sebanyak 23 pernyataan internal (dengan kode I1 - I23) dan 11 pernyataan eksternal (dengan kode E1 E11) Kuesioner yang sudah melalui tahap item analysis melalui uji reliabilitas dan validitas selanjutnya dipergunakan untuk mengumpulkan data. Sebanyak 100 kuesioner yang valid telah dikumpulkan, dimana untuk selanjutnya data tersebut dianalisis dengan teknik analisis faktor, yaitu Exploratory Factor Analysis (EFA). Jumlah sampel ditentukan sebanyak 100 responden. Jumlah tersebut sudah memenuhi ketentuan jumlah sampel untuk analisis faktor (Kline, 2000; Hair Jr, dkk, 2014).

\section{HASIL DAN PEMBAHASAN}

Untuk menentukan potensi desa wisata di Desa Penglipuran, analisis faktor dilakukan sebanyak 2 (dua) kali, 
masing-masing terhadap kelompok pernyataan internal dan eksternal. Analisis faktor untuk kelompok pernyataan internal dilakukan untuk mengetahui apakah faktor baru yang terbentuk merupakan kekuatan (strength) ataukah kelemahan (weakness), sedangkan analisis faktor yang dilakukan terhadap kelompok pernyataan eksternal dilakukan untuk melihat apakah faktor yang terbentuk merupakan faktor yang tergolong peluang (opportunity) ataukah ancaman (threat).

\subsection{Analisis Faktor Terhadap Kelompok Pernyataan Internal.}

Setalah dilakukan analisis dengan Analisis Faktor, diperoleh beberapa nilai untuk diinterpretasi. Nilai pertama adalah nilai Kaizer Mayer Olkin (KMO), yang menunjukkan kecukupan sampel untuk dianalisis lebih lanjut dengan Analisis Faktor. Hasil pengukuran menunjukkan nilai KMO sebesar 0,721, dimana nilai tersebut diistilahkan sebagai middling yang tergolong nilai yang bagus (Field, 2017), dimana syarat minimum nilai KMO adalah lebih besar atau sama dengan 0,5 . Jika nilainya di bawah 0,5, itu berarti jumlah sampel harus ditambah. Nilai Bartlett's Test of Sphericity juga telah memenuhi syarat karena nilainya menunjukkan nilai sebesar 0,00 yang telah memenuhi syarat karena tidak melebihi 0,05 (Fields, 2017). Persyaratan communalities juga telah dipenuhi, karena nilainya untuk seluruh indikator adalah $\geq 0,5$ (Hair Jr, 2014).

Pemeriksaan terhadap total variance explain menunjukkan bahwa dengan metode ekstraksi Principal Componen Analysis (PCA), dengan menentukan nilai eigenvalue $\geq 1$, pernyataan-pernyataan dalam kelompok pernyataan internal mengelompok menjadi 6 kelompok faktor yang menunjukkan potensi Desa Wisata Penglipuran secara internal. Berdasarkan nilai Rotation Sums of Squared Loadings terlihat bahwa keenam faktor yang terbentuk mampu menjelaskan sebanyak 66,676\% dari matriks data awal. Terbentuknya 6 faktor baru juga bisa dilihat dengan memeriksa scree plot, dimana pada diagram scree plot terlihat bahwa ada 6 titik yang mewakili 6 faktor baru dengan nilai $\geq 1$. Hal tersebut mengkonfirmasi hasil pemeriksaan terhadap total variance explaines, bahwa terdapat 6 kelompok faktor baru pada kelompok pernyataan internal yang terbentuk.

Untuk mengetahui pernyataan apa saja yang mengelompok untuk membentuk faktor baru, dapat dilakukan dengan mencermati nilai-nilai pada rotated component matrix. Nilai yang diharapkan pada matrik tersebut adalah nilai yang melebihi 0,70 (Hair Jr, 2014). Jika nilai korelasinya kurang dari 0,70 , maka pernyataan tersebut tidak dianggap sebagai pernyataan pembentuk sebuah faktor. Demikian pula jika sebuah pernyataan berkorelasi dengan hampir sama kuat dengan 2 (dua) faktor, maka pernyataan tersebut sebaiknya dihilangkan karena akan menyulitkan dalam mengasosiasikan pernyataan tersebut ke dalam salah satu faktor.

Berdasarkan rotated componen matrix diketahui bahwa Faktor 1, terbentuk dari 3 (tiga), yaitu pernyataan I24, I22 dan I23. Faktor 2, terbentuk dari 4 (empat) pernyataan, yaitu I3, I1, I4 dan I2. Faktor 3, terbentuk dari pernyataan dua (2) pernyataan, yaitu I12 dan I13. I18 dan I19 merupakan 2 (dua) pernyataan pembentuk Faktor 4, sedangkan pernyataan I8, I9 dan I7 merupakan 3 pernyataan yang mengelompok dan membentuk Faktor 5. Satu-satunya faktor yang terbentuk oleh 1 pernyataan adalah faktor 6 , yang dibentuk oleh pernyataan I5.

Berdasarkan pernyataanpernyataan pembentuknya, faktor baru yang terbentuk pada kelompok pernyataan internal selanjutnya diberikan nama sebagai berikut:

Faktor 1: Popularitas Desa Wisata Penglipuran sebagai destinasi pariwisata alam dan budaya di 
Suasapha

kalangan pengunjung mancanegara dan domestik.

Faktor 2: Desa Wisata Penglipuran memiliki daya tarik wisata budaya dan alam yang menarik yang bersumber dari budaya dan alamnya yang menarik.

Faktor 3 : Desa Wisata Penglipuran dikelola secara professional oleh pengelola yang professional.

Faktor 4 : Aksesibilitas di dalam wilayah Desa Wisata Penglipuran sangat baik.

Faktor 5 : Lingkungan Desa Wisata Penglipuran rapi, tertib, bersih dan aman

Faktor 6 : Aktivitas wisata yang dapat dilakukan di Desa Wisata Penglipuran bervariasi.

Jika dilihat kembali, uraian di atas menunjukkan bahwa 6 faktor baru tersebut terbentuk oleh 15 penyataan dari 23 pernyataan yang membentuk kelompok pernyataan internal. Kelima belas (15) pernyataan tersebut merupakan pernyataan-pernyataan yang memperoleh persetujuan dari para responden. Mengingat rancangan pernyataan dalam kuesioner yang digunakan untuk mengumpulkan data adalah dalam bentuk kalimat positif, maka dengan sendirinya kelima belas (15) pernyataan tersebut dapat dianggap sebagai kekuatan (strengths) dari Desa Wisata Penglipuran. Karena itu, keenam (6) faktor yang terbentuk dapat dianggap sebagai 6 kekuatan (strengths) dari Potensi Desa Wisata Penglipuran.Adapun 8 pernyataan yang tidak ikut membentuk 6 faktor baru merupakan pernyataanpernyataan yang tidak memperoleh persetujuan (respon positif) dari responden. Mengingat pernyataanpernyataan tersebut juga tersususun dalam bentuk kalimat positif, maka kedelapan (8) pernyataan tersebut merupakan kelemahan (weaknesses) dari Desa Wisata Penglipuran.

\subsection{Analisis Faktor Terhadap Kelompok Pernyataan Eksternal}

Analisis faktor terhadap pernyataanpernyatan dalam kelompok pernyataan eksternal menghasilkan beberapa nilai untuk diinterpretasi. Nilai KMO dan Bartlett's Test menunjukkan angka berturut-turut sebesar 0,7070 dan 0,000, yang mana kedua angka tersebut mengindikasikan hal yang baik. Dengan nilai KMO sebesar 0,707, dapat diketahui bahwa junmlah sampel telah memenuhi syarat untuk menghasilkan faktor baru. Nilai hasil Bartlett's Test of Spericity juga telah memenuhi syarat karena nilainya tidak melebihi 0,05. Hasil pemeriksaan terhadap Communality juga menunjukkan hasil yang baik. Kesebelas (11) pernyataan dalam kelompok pernyataan eksternal memiliki nilai communalities yang melebihi 0,5 , yang berarti bahwa kesebesal pernyataan tersebut memiliki peluang untuk menjadi penyusun faktor baru.

Kesebelas pernyataan tersebut selanjutnya diekstraksi. Dengan menentukan nilai eigenvalue lebih besar atau sama dengan 1, diperoleh hasil bahwa pernyataan-pernyataan mengelompok menjadi 4 kelompok faktor baru, dimana nilai total variance explain menyatakan bahwa keempat faktor yang terbentuk mewakili sebesar $72, \quad 836 \%$ dari matriks awal. Terbentuknya 4 faktor baru juga terkonfirmasi dari grafik Scree Plot yang dengan jelas menunjukkan ada 4 komponen (pernyataan) yang memiliki nilai eigenvalue $\geq 1$.

Rotated componen matrix menunjukkan bahwa ada 10 pernyataan yang memiliki nilai korelasi yang baik dengan faktor yang dibentuknya, dengan nilai-nilai yang telah memenuhi syarat yaitu $\geq 0,7$. Nilai yang tidak memenuhi syarat untuk menjadi pembentuk faktor baru adalah E4, dengan nilai korelasi 0,640 , lebih rendah dari 0,7 yang menjadi syarat untuk menjadi pembentuk faktor baru (Hair Jr, 2014). Adapun keempat faktor pada kelompok pernyataan eksternal yang terbentuk 
adalah Faktor 1 yang terbentuk dari pernyataan E2, E3 dan E1, Faktor 2, terbentuk dari pernyataan E11, E12 dan E10, Faktor 3, terbentuk dari pernyataan E7 dan E5 dan Faktor 4, terbentuk dari pernyataan E9 dan E8. Keempat faktor baru tersebut selanjutnya diberikan nama berdasarkan pernyataanpernyataan pembentuknya. Adapun nama faktor-faktor tersebut adalah sebagai berikut:

Faktor 1 : Ada desa wisata lain yang memiliki daya tarik wisata budaya, aktifitas wisata, serta daya tarik wisata alam seperti yang dimiliki Desa Wisata Penglipuran.

Faktor 2 : Pemerintah Kabupaten Bangli mendampingi pengembangan Desa Adat Penglipuran melalui penyediaan perangkat aturan, penyediaan prasarana penunjang dan kegiatan peningkatan kapasitas masyarakat dan pengelola Desa Wisata Penglipuran.

Faktor 3 : Lokasi Desa Wisata Penglipuran dilalui oleh jalan raya dengan kualitas yang baik, dan merupakan jalur wisata dengan berbagai daya tarik yang bisa dikombinasikan dengan Desa Wisata Penglipuran sebagai paket wisata.

Faktor 4: Informasi pariwisata mengenai Desa Wisata Penglipuran tersedia dengan baik secara online maupun offline.

Kesepuluh (10) pernyataan pembentuk empat (4) faktor pada kelompok pernyataan eksternal merupakan pernyataan-pernyataan yang memperoleh respon positif dari responden. Mengingat pernyataanpernyataan tersebut tersusun dalam format pernyataan positif, maka dapat dinyatakan bahwa kesebelas pernyataan tersebut tergolong sebagai potensi dalam bentuk peluang (Opportunities) bagi Desa Wisata Penglipuran. Karena itu, keempat faktor yang dibentuknya merupakan peluang-peluang (opportunities) yang diliki oleh Desa Wisata Penglipuran. Adapun 1 pernyataan yang nilai korelasinya kurang dari 0,7, merupakan satusatunya pernyataan yang dapat dianggap sebagai tantangan (threat) yang dihadapi oleh Desa Wisata Penglipuran.

\section{KESIMPULAN}

Analisis faktor yang dilakukan terhadap kelompok pernyataan internal menghasilkan 6 faktor yang tergolong sebagai kekuantan (strengths) dari Desa Wisata Penglipuran. Di sisi lain, analisis faktor yang dilakukan terhadap kelompok pernyataan eksternal, menghasilkan 4 faktor baru yang tergolong sebagai peluang (opportunities). Adapun kekuatan (strengths) dari Desa Wisata Penglipuran adalah 1). Popularitas Desa Wisata Penglipuran sebagai destinasi pariwisata alam dan budaya di kalangan pengunjung mancanegara dan domestik, 2). Desa Wisata Penglipuran memiliki daya tarik wisata budaya dan alam yang menarik yang bersumber dari budaya dan alamnya yang menarik, 3). Desa Wisata Penglipuran dikelola secara professional oleh pengelola yang professional, 4). Aksesibilitas di dalam wilayah Desa Wisata Penglipuran sangat baik, 5) Lingkungan Desa Wisata Penglipuran rapi, tertib, bersih dan aman dan 6). Aktivitas wisata yang dapat dilakukan di Desa Wisata Penglipuran bervariasi.

Peluang (opportunities) dari Desa Wisata Penglipuran adalah: 1). Ada desa wisata lain yang memiliki daya tarik wisata budaya, aktifitas wisata, serta daya tarik wisata alam seperti yang dimiliki Desa Wisata Penglipuran, 2). Pemerintah Kabupaten Bangli mendampingi pengembangan Desa Adat Penglipuran melalui penyediaan perangkat aturan, penyediaan prasarana penunjang dan kegiatan peningkatan kapasitas masyarakat dan pengelola Desa Wisata Penglipuran, 3). Lokasi Desa 
Suasapha

Wisata Penglipuran dilalui oleh jalan raya dengan kualitas yang baik, dan merupakan jalur wisata dengan berbagai daya tarik yang bisa dikombinasikan dengan Desa Wisata Penglipuran sebagai paket wisata, dan 4). Informasi pariwisata mengenai Desa Wisata Penglipuran tersedia dengan baik secara online maupun offline.

Penelitian yang mendasari penulisan artikel ini dilaksanakan hanya sampai pada penentuan potensi Desa Wisata Penglipuran. Untuk selanjutnya, dengan perpatokan terhadap potensi dari sisi internal dan eksternal yang telah diketahui, dapat dilakukan penelitian lanjutan untuk merumuskan strategi pengembangan potensi desa wisata tersebut.

\section{DAFTAR PUSTAKA}

Burkart, A. d. (1976). Tourism Past Present and Future. London: Heinemann.

Calzada, I., \& Cowie, P. (2017). Beyond Smart \& Data-Driven City-Regions? Rethinking Stakeholder-Helixes Strategies. Regions Magazine. RSA Regional Studies Association (Gail Mulvey \& Frank Peck).

Cooper, C. (2016). Essentials Of Tourism Second Edition. Harlow: Pearson Education Limited.

David, F. R. (2011). Strategic Management Concepts and Cases. New Jersey: Pearson. Field, A. (2017). Discovering Statistics Using IBM SPSS Statistics 5 th Edition. Sussex: Sage Edge.

Fletcher, J., Fyall, A., Gilbert, D., \& Wanhil, S. (2018). Tourism Principles And Practice. Harlow: Pearson Education Limited.

Joseph H. H. Jr, W. C. (2014). Multivariate Data Analysis Seventh Edition. Essex: Pearson Education Limited.

Kencana, I. P. (2018). Materi Tutorial Analisis Kuantitatif Data Pariwisata. Denpasar: Konsorsium Riset Pariwisata Universitas Udayana.
Kline, P. (2000). The Handbook of Psychological Testing Second Edition . London and New York: Routledge.

Likert, R. (1932). A Technique For The Measurement of Attitudes. (R. Woodworth, Ed.) Archives Of Psychology, 140, 5 - 55.

Nunnaly, J. C., \& Bernstein, I. H. (1994). Psychometric Theory Third edition. New York: McGraw-Hill Inc.

Penglipuran Bali: World's Third Cleanest Village. (2018, March 7). Retrieved September 2, 2020, from indonesia.travel: www.indonesia.travel

UNWTO. (2007). A Practical Guide to Tourism Destination Management. Madrid: UNWTO.

UNWTO. (2016). Global Report on The Power Of Youth Travel, Volume Thirteen. Madrid, Spain: UNWTO. 